\title{
Effects of Oxygen Levels on the Transcription of nif and $g l n$ Genes in Bradyrhizobium japonicum
}

\author{
By THOMAS H. ADAMS*† AND BARRY K. CHELM \\ MSU/DOE Plant Research Laboratory and the Department of Microbiology, \\ Michigan State University, East Lansing, Michigan 48824, USA
}

(Received 13 July 1987; revised 28 September 1987)

\begin{abstract}
The transciption of genes that function in $\mathrm{N}_{2}$ fixation (nif) and nitrogen assimilation ( $\mathrm{glnII}$ ) in Bradyrhizobium japonicum is coordinately induced in response to $\mathrm{O}_{2}$ limitation as well as symbiotic development. We have determined the relative steady-state mRNA levels for the nifH, nif $D K$ and $g \ln I I$ transcription units in bradyrhizobial cells grown under a variety of levels of aerobiosis and in cells isolated from soybean root nodules. All three transcripts are found in cells grown in a rich medium sparged with $\mathrm{O}_{2}$ concentrations of $5 \%(\mathrm{v} / \mathrm{v})$ or less. This expression is qualitatively similar to that observed for Bradyrhizobium during symbiotic development. Potential physiological mechanisms for the coordinate control of these genes are discussed.
\end{abstract}

\section{INTRODUCTION}

Rhizobia and bradyrhizobia reduce atmospheric $N_{2}$ in symbiotic association with their leguminous host plants. Development of symbiotic $\mathrm{N}_{2}$ fixation is a complex process requiring the coordinate differentiation of both plant and bacterial cells. This differentiation results in the formation of morphologically and functionally distinct $\mathrm{N}_{2}$-fixing endosymbiont bacteria termed 'bacteroids'. Very little of the ammonia produced from $\mathrm{N}_{2}$ reduction by bacteroids is used to support bacterial growth (Brown \& Dilworth, 1975; Stripf \& Werner, 1978; Werner et al., 1980): most of it is exported (Bergerson \& Turner, 1967) to the plant where it is assimilated (Miflin \& Lea, 1976). The plant supplies reduced carbon compounds to the bacteria to meet the high energy demands of $\mathrm{N}_{2}$ fixation and cell maintenance.

Nitrogen metabolism during asymbiotic $\mathrm{N}_{2}$ fixation by bradyrhizobia is similar to that observed in bacteroids, as most of the fixed nitrogen is not used to support growth, but is instead exported (O'Gara \& Shanmugan, 1976; Bergerson \& Turner, 1978; Ludwig, 1980a, $b$ ). For at least some bradyrhizobial strains this failure to assimilate fixed nitrogen is partly due to an apparent decrease in glutamine synthetase (GS) activity (Ludwig, 1980a, $b$; Bergerson \& Turner, 1978). Regulation of GS activity in rhizobia and bradyrhizobia is complicated by the fact that these bacteria contain two isoforms of the enzyme, GSI and GSII (Darrow \& Knotts, 1977). The two distinct nitrogen-assimilatory enzymes are encoded by separate genes (Somerville \& Kahn, 1983; Carlson \& Chelm, 1986), and transcription of the genes is differentially regulated. Transcription of the gene encoding GSI $(g \ln A)$ is constant under all conditions (Carlson et al., 1985). This enzyme is regulated post-translationally via adenylylation, such that activity decreases during growth in nitrogen-rich media (Bishop et al., 1976; Ludwig, 1978). In contrast, no post-translational modification of GSII has been observed. Transcription of the gene encoding GSII ( $g \ln I I)$ under aerobic growth conditions is controlled by a mechanism that resembles the $\mathrm{Ntr}$ system (Carlson et al., 1987) of enteric bacteria (Magasanik, 1982; Gussin et al., 1986); growth conditions that limit nitrogen source activate transcription of the glnII gene.

$\dagger$ Present address: Department of Genetics, University of Georgia, Athens, Georgia 30602, USA.

$\ddagger$ This paper is dedicated to the memory of Barry Chelm.

Abbreviation: GS, glutamine synthetase.

0001-4296 (C) 1988 SGM 
We are interested in understanding the mechanisms through which $g \ln$ and nif gene expression is controlled in Bradyrhizobium japonicum, a soybean symbiont, during symbiotic $\mathrm{N}_{2}$ fixation as well as in free-living cultures. Some bradyrhizobial strains can be induced to fix $\mathrm{N}_{2}$ in free-living culture under specialized conditions (Keister, 1975; Pagan et al., 1975; Kurz \& Larue, 1975; McComb et al., 1975; Tjepkema \& Evans, 1975). These conditions include both provision of a source of fixed nitrogen (preferably glutamate) and the presence of $\mathrm{O}_{2}$ as an electron acceptor for oxidative phosphorylation. The requirement for $\mathrm{O}_{2}$ in these systems presents a difficulty as the nitrogenase enzyme is inactivated by $\mathrm{O}_{2}$. The partial pressure of $\mathrm{O}_{2}$ must be maintained at levels that are high enough to allow the oxidative phosphorylation levels necessary to provide the ATP required for $\mathrm{N}_{2}$ reduction, and low enough to prevent the irreversible inactivation of nitrogenase (Mortenson \& Thornley, 1979). We have chosen to simplify the analysis by directly analysing the effect of microaerobiosis on $n$ if transcription. We have determined the relative steady-state mRNA levels for the $n i f H, n i f D K, g \ln A$ and $g \ln I I$ transcription units in bradyrhizobial cells grown under varying levels of aerobiosis. The results indicate that nifH, nifDK and $g \ln I I$ transcription is coordinately induced in response to both symbiotic development and microaerobic growth.

\section{METHODS}

Bacterial strains, media and growth conditions. All of the experiments in this paper used a small-colony derivative of B. japonicum 311b110, which we term BJ110, isolated as described previously (Kuykendall \& Elkan, 1976; Meyer \& Pueppke, 1980). Bacteria were grown in YEM $\left(0.04 \%\right.$ yeast extract, $1 \%$ mannitol, $3 \mathrm{mM}-\mathrm{K}_{2} \mathrm{HPO}_{4}$, $0.8 \mathrm{mM}^{-\mathrm{MgSO}_{4}}, 1.1 \mathrm{mM}-\mathrm{NaCl}$ ), YEMN (YEM with $10 \mathrm{mM}-\mathrm{KNO}_{3}$ ), or YEMNA (YEMN with $10 \mathrm{mM}-\mathrm{NH}_{4} \mathrm{Cl}$ ) media. Ten-litre cultures of $B$. japonicum were grown using Microferm fermenters (New Brunswick Scientific) agitated at 200 r.p.m. and sparged with mixtures of $\mathrm{O}_{2}$ and $\mathrm{N}_{2}$ at rates of $500 \mathrm{ml} \mathrm{min}^{-1}$. Gas flow rates were controlled using thermal mass flowmeters (Brooks Instruments, model $5850 \mathrm{C}$ ) to provide the atmospheric $\mathrm{O}_{2}$ concentrations reported. Inoculation was with $100 \mathrm{ml}$ of a stationary-phase aerobic culture in YEM medium.

Nucleic acid techniques. Methods for RNA isolation were as described previously (Adams \& Chelm, 1984).

mRNA abundances were measured by a quantitative $S 1$ nuclease protection method in which multiple mRNAs could be simultaneously quantified from a single reaction. Single-stranded 5 ' end-labelled probes were synthesized by primer extension as follows. A gene-specific oligonucleotide $(80 \mathrm{ng})$ was labelled by reaction with T4 polynucleotide kinase at $37^{\circ} \mathrm{C}$ for $1 \mathrm{~h}$ in $100 \mathrm{mM}$-Tris/ $\mathrm{HCl}, \mathrm{pH} 7.5,10 \mathrm{mM}-\mathrm{MgCl}_{2}, 6 \mathrm{mM}$-dithioerythritol and $100 \mu \mathrm{Ci}\left[\gamma^{-32} \mathrm{P}\right] \mathrm{ATP}$ (approx. $3000 \mathrm{Ci} \mathrm{mmol}^{-1}, 111 \mathrm{TBq} \mathrm{mmol}^{-1}$ ). In the experiments with mixed probes, the specific activity of each $5^{\prime}$ end-labelled oligomer was adjusted to approximately 250 d.p.m. pg $^{-1}$ with unlabelled oligonucleotide prior to the elongation reaction. The labelled primers were combined with $20 \mu \mathrm{g}$ of the appropriate single-stranded M13 recombinant phage template DNA, ethanol-precipitated, suspended in $50 \mu \mathrm{l} 10 \mathrm{mM}-$ Tris/ $\mathrm{HCl}$, pH 8.5 , and $10 \mathrm{mM}-\mathrm{MgCl}_{2}$, heated for $5 \mathrm{~min}$ at $90^{\circ} \mathrm{C}$, and allowed to hybridize for $1 \mathrm{~h}$ at $37^{\circ} \mathrm{C}$. The hybridized oligonucleotide primer was extended using 3 units (Bethesda Research Laboratories) of the large fragment of Escherichia coli DNA polymerase (Klenow fragment) for $1 \mathrm{~h}$ at $37^{\circ} \mathrm{C}$ in $100 \mu \mathrm{l}$ of the same buffer plus $0.6 \mathrm{mM}$ each of dATP, dCTP, dGTP and dTTP. The reaction was stopped by heating at $65^{\circ} \mathrm{C}$ for $5 \mathrm{~min}$. The partially double-stranded DNA was ethanol-precipitated and resuspended in the appropriate restriction endonuclease buffer. To prepare the probes specific for the $n i f H$ and nifDK promoters, the product of the extension reaction was digested with $B s t \mathrm{NI}$ for $3 \mathrm{~h}$ at $58{ }^{\circ} \mathrm{C}$, ethanol-precipitated, and suspended in $200 \mu \mathrm{l} 80 \%(\mathrm{v} / \mathrm{v})$ formamide with tracking dyes. The $g \ln A$ and $g \ln I I$ probes were prepared by digestion with $\operatorname{Sall}$ for $3 \mathrm{~h}$ at $37^{\circ} \mathrm{C}$. After denaturation by incubation at $100^{\circ} \mathrm{C}$ and purification by electrophoresis on $8.4 \mathrm{M}$-urea, $4 \%(\mathrm{w} / \mathrm{v})$ polyacrylamide gels, the labelled, single-stranded probe was detected by autoradiography and eluted by the crushand-soak method (Maxam \& Gilbert, 1980.)

The following recombinant M13 phages were constructed for use in synthesizing single-stranded DNA hybridization probes: M13H has a 704 bp BamHI-HindIII fragment from nifH and its upstream region (Adams \& Chelm, 1984) in M13mp19; M13DK contains a 417 bp Pst I-SphI fragment from the promoter region of the nifDK operon (Adams \& Chelm, 1984) in M13mp19; M13glnII has the 2.1 kbp Sall fragment of pBJ196 containing the $g l n I I$ promoter region (Carlson \& Chelm, 1986) in M13mp18; and M13glnA has a 391 bp Sall fragment from the promoter region of $g \ln A$ (Carlson et al., 1985) in M13mp18. Oligonucleotides for primer extension were synthesized and purified as described previously (Carlson \& Chelm, 1986). The sequences of each primer were as follows: 5'-TGCTCTCCATCAACCGA (nifH); 5'-CTTCACCCCGCAGTCCG (nifDK); 5'CCCCTTTTGGCTCTGCG $(g \ln A)$; and 5 -CGACGCGAATTCCTTGA $(g \ln I)$. The partially protected fragments from $S 1$ analyses with each of the probes generated by elongation of these primers are 150, 200,125, and 170 nucleotides long, respectively. For mixed-probe experiments, approximately $6 \times 10^{-15}$ mol of each $5^{\prime}$ endlabelled single-stranded fragment was included in the hybridization. For the driver RNA quantities used in these 
experiments, this proved to be an excess of probe since increasing RNA concentrations resulted in a proportional increase in the amount of hybrid detected (data not shown). Hybridization, S1 digestion, and identification of partially protected products were as described previously (Adams \& Chelm, 1984).

Isolation of bacteria from soybean root nodules. Total bacterial populations from frozen soybean nodules were prepared as described previously (Adams \& Chelm, 1984). Separation of these bacteria into the three developmental fractions, as first described by Ching et al. (1977), was done by two rounds of centrifugation through discontinuous sucrose gradients using a zonal ultracentrifuge rotor (Beckman 14Ti) as described by Carlson et al. (1985).

\section{RESULTS}

\section{Effects of $\mathrm{O}_{2}$ concentration on $\mathrm{B}$. japonicum gene expression}

To study the role of $\mathrm{O}_{2}$ limitation in regulating $n i f$ and $g l n$ gene expression for $B$. japonicum, we examined total cellular RNA isolated from $B$. japonicum cultures grown in standard nitrogenrich media at a variety of $\mathrm{O}_{2}$ concentrations. The results for one such set of experiments are shown in Fig. 1. The expression levels of the nifH, nifDK, $g \ln I I$ and $g \ln A$ genes were monitored using a quantitative $\mathrm{S} 1$ protection assay system. Equal quantities of four single-stranded, $5^{\prime}$ endlabelled DNA probes specific for the nifH, nifDK, $g \ln I I$ and $g \ln A$ promoters were mixed and hybridized to total cellular RNA under conditions where the probes were in excess to the respective RNAs (see Methods). After hybridization, the mixtures were treated with S1 nuclease and the residual undigested DNA fragments then separated by gel electrophoresis. The hybridization probes were designed such that the protected fragments would be well resolved on the gel, allowing for the simultaneous measurement of transcript abundance for all four genes using a single RNA sample. The radioactive content for each band on the gel was determined directly (see Methods). RNA abundance is reported as c.p.m. protected DNA probe per $\mu \mathrm{g}$ driver RNA and is taken from a point within the linear range of the RNA:probe titration.

When $B$. japonicum was grown in a standard rich medium (YEMN) continuously sparged with air, no transcript for the nifH, nifDK or $g \ln I I$ genes was observed (Fig. 1, lane 1, and Table 1). In contrast, the transcript from the $g \ln A$ gene was present, as reported previously (Carlson et al., 1985). We have observed only small variations in $g \ln A$ transcript levels between any two culture conditions. If $B$. japonicum was cultured in this same medium but continuously sparged with a mixture of $\mathrm{N}_{2}$ and $\mathrm{O}_{2}$ such that $\mathrm{O}_{2}$ availability limited growth $\left(5 \% \mathrm{O}_{2}\right.$ or less in the YEMN experiments), then expression of all four transcription units was observed (Fig. 1, Table 1). Similar cultures were grown either with (YEMN) or without (YEM) added $\mathrm{KNO}_{3}$. Under microaerobic conditions, $\mathrm{KNO}_{3}$ helps to stimulate growth by serving as an alternative electron acceptor (Daniel et al., 1982; M. L. Guerinot \& B. K. Chelm, unpublished). A similar pattern for the relative levels of transcripts for any of the genes monitored was observed but the oxygen concentration dependence was shifted (Table 1). A three- to fourfold decrease in mRNA abundance for nifH, nifDK and $g$ InII was observed as $\mathrm{O}_{2}$ levels were increased above $1 \%$ in YEMN medium or above $0.1 \%$ in YEM medium. Despite the high levels of the two nif mRNAs observed in these cultures, no nitrogen-fixation activity, as measured by the acetylene reduction assay (Hardy et al., 1968), was detectable, in agreement with previous reports (e.g. Scott et al., 1979). Transcription of the nif $B$ and $f x A$ genes was also analysed (data not shown) and results identical to those obtained for nifH, nifDK and $g \ln I I$ were obtained.

\section{Effect of ammonia on microaerobic growth and gene expression}

Under aerobic growth conditions, $g \ln I I$ transcription is induced when growth is limited by a poor nitrogen source to carbon source balance (Carlson et al., 1987). Presumably this activation is an attempt by the cells to maximize their capacity to assimilate nitrogen. Conversely, limitation of growth by carbon source does not induce glnII transcription, presumably because increased nitrogen assimilation would not increase growth. This control is similar to the Ntr control system which operates in the Enterobacteriaceae (Magasanik, 1982). To determine whether the microaerobic induction of $g \ln I I$ and nif gene transcription described above is under Ntr-like control, B. japonicum grown under microaerobic conditions in YEMN medium was

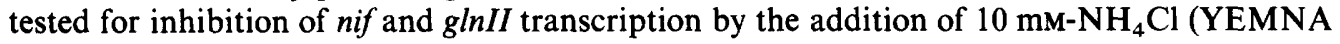




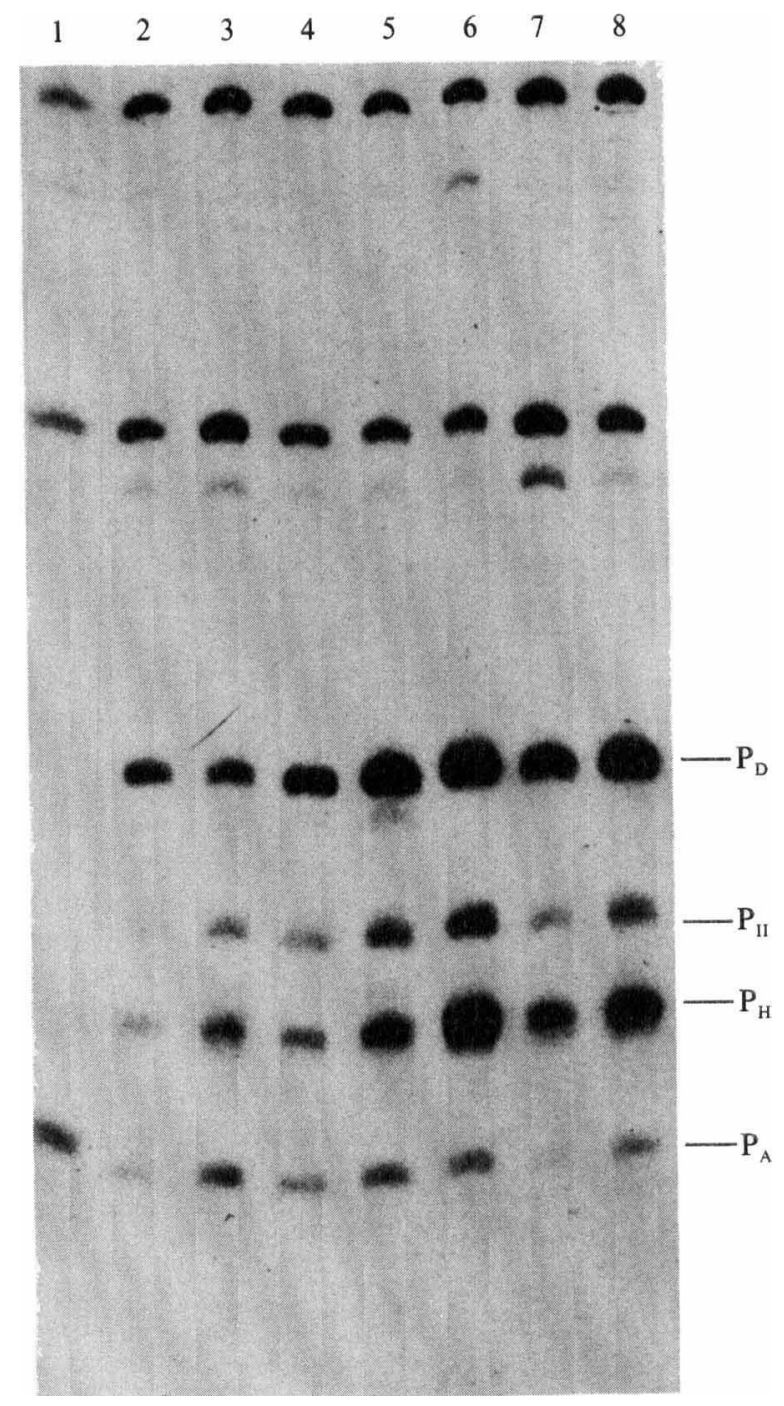

Fig. 1. A typical abundance measurement for the nif $H$, nifD $K, g \ln I I$ and $g \ln A$ transcripts. B. japonicum was grown under a variety of atmospheric $\mathrm{O}_{2}$ concentrations. Quantitative analyses were by the $\mathrm{S} 1$ protection method described in Methods. The migration positions of the four protected fragments are indicated by $\mathrm{P}_{\mathrm{D}}\left(\right.$ nifDK), $\mathrm{P}_{\mathrm{II}}(g \ln I I), \mathrm{P}_{\mathrm{H}}($ nifH $)$ and $\mathrm{P}_{\mathrm{A}}(g \ln A)$. The other major radioactive bands observed represent residual undigested probe DNA. The total cellular RNAs used in the hybridization reactions ( $2 \mu \mathrm{g}$ RNA in each) were isolated from $B$. japonicum cultured under the following conditions: $20 \%(\mathrm{v} / \mathrm{v}) \mathrm{O}_{2}$ in YEMN (lane 1); $0.2 \% \mathrm{O}_{2}$ in YEMNA (lane 2); $5 \% \mathrm{O}_{2}$ in YEMN (lane 3 ) $; 2 \% \mathrm{O}_{2}$ in YEMN (lane 4); $1 \% \mathrm{O}_{2}$ in YEMN (lane 5); $0.4 \% \mathrm{O}_{2}$ in YEMN (lane 6); $0.2 \% \mathrm{O}_{2}$ in YEMN (lane 7); and $0.1 \% \mathrm{O}_{2}$ in YEMN (lane 8). All media and growth conditions are described in Methods.

medium). The final cell density of microaerobic cultures grown in YEMNA media is more than twice that of cultures grown in YEMN (data not shown). Microaerobic induction of $g \ln I I$, as well as nifH and nifDK, could therefore be due, directly or indirectly, to an Ntr-like response similar to aerobic $g \ln I I$ induction. When total cellular RNA was isolated from YEMNA cultures and assayed for $g \ln I I, n i f H, n i f D K$ and $g \ln A$ expression, transcript levels for all but $g \ln A$ were significantly and reproducibly reduced by the addition of ammonia (Table 1). 
Table 1. Effects of $\mathrm{O}_{2}$ concentration on transcription of nif and gln genes

\begin{tabular}{|c|c|c|c|c|c|c|c|c|c|}
\hline \multirow[b]{3}{*}{ Medium* } & \multirow[b]{3}{*}{ Probe } & \multicolumn{8}{|c|}{ mRNA abundance $\dagger$} \\
\hline & & \multicolumn{8}{|c|}{$\mathrm{O}_{2}$ concentration $(\%, v / v)$} \\
\hline & & $0 \cdot 1$ & $0 \cdot 2$ & 0.4 & $1 \cdot 0$ & $2 \cdot 0$ & $5 \cdot 0$ & $10 \cdot 0$ & $20 \cdot 0$ \\
\hline \multirow[t]{4}{*}{ YEM } & nifDK & 380 & 56 & 36 & 78 & - & - & - & - \\
\hline & nifH & 295 & 22 & 20 & 23 & - & - & - & - \\
\hline & $g \ln I I$ & 101 & 27 & 9 & 45 & - & - & - & - \\
\hline & $g \ln A$ & 44 & 12 & 11 & 18 & - & - & - & - \\
\hline \multirow[t]{4}{*}{ YEMN } & nifDK & 161 & 175 & 231 & 211 & 110 & 59 & 0 & 0 \\
\hline & nifH & 133 & 72 & 157 & 151 & 59 & 75 & 0 & 0 \\
\hline & $g \ln I I$ & 51 & 43 & 72 & 63 & 24 & 25 & 0 & 0 \\
\hline & $g \ln A$ & 34 & 23 & 34 & 37 & 29 & 35 & 31 & 18 \\
\hline \multirow[t]{4}{*}{ YEMNA } & nifDK & - & 62 & - & - & - & - & - & - \\
\hline & nifH & - & 42 & - & - & - & - & - & - \\
\hline & $g \ln I I$ & - & 11 & - & - & - & - & - & - \\
\hline & $g \ln A$ & - & 21 & - & - & - & - & - & - \\
\hline
\end{tabular}

* Media and growth conditions were as described in Methods. Carbon and nitrogen sources are abbreviated as follows: YE, yeast extract; $M$, mannitol; $N$, nitrate; $A$, ammonia.

† C.p.m. of hybridization probe protected from S1 nuclease digestion per $\mu \mathrm{g}$ of input total cellular RNA. This indicates the relative steady-state mRNA level for each gene. Data represent a mean value determined from two separate experiments. Variations between experiments were less than $20 \%$. -, Not determined; 0 , transcript levels were below the limit of detection of the assay.

\section{Growth phase dependence of microaerobic nif and gln transcription}

Previous studies on the role of microaerobiosis for nonsymbiotic nif gene induction in bradyrhizobia have relied upon the expression of nitrogenase enzyme activity. Those studies indicate that the presence of nitrogenase activity in free-living cultures of bradyrhizobia usually requires that the cells have stopped growing (e.g. Ludwig, 1984). For this reason, the cultures used for the experiments described above were grown for $2 \mathrm{~d}$ into stationary phase prior to harvesting (with the exceptions of the 1,2 , and $5 \% \mathrm{O}_{2}$ cultures, which were harvested earlier due to more rapid growth). To determine whether the microaerobic transcriptional induction of glnII and nif genes has a growth phase requirement like that for nitrogenase activity, cells were harvested at different times during microaerobic growth and the abundances of the nif and $g l n$ transcripts were determined. The nifH, nifDK and $g \ln I I$ transcripts were all found at near maximal levels within $24 \mathrm{~h}$ of inoculation and expression remained at high levels throughout the $120 \mathrm{~h}$ growth period analysed (data not shown). These cultures do not enter stationary growth phase for at least $72 \mathrm{~h}$ (not shown).

\section{Transcription of nif and gln genes during symbiotic development}

In order to evaluate the role of bacteroid development in nif and $g$ ln transcription, RNA was isolated from the bacteria within $B$. japonicum induced soybean root nodules and mRNA levels were determined. Two weeks after sowing and inoculation, transcript levels for both nif operons ranged up to four-fold higher in the nodule bacteria population than under any of the microaerobic growth conditions tested (Table 2). Transcript abundances for the nifH and nifDK genes were approximately equal under the microaerobic conditions. In contrast, bacterial RNA from soybean root nodules had an increased ratio of nifH to nifDK message, with nifH transcript about twice as abundant as that for nifDK. This was accomplished mainly through an increase in the steady-state mRNA levels for nifH. Whether these differences represent changes in transcription rate or changes in mRNA stability has not yet been determined. The $g \ln I I$ transcript levels in the nodule bacterial cell populations were approximately equal to those seen in microaerobic culture.

A method for fractionating the mixed populations of bacteria isolated from within soybean root nodules has been described (Ching et al., 1977; Carlson et al., 1985). This technique relies 
Table 2. $m R N A$ abundance of nif and gln genes during symbiotic development

RNA source
Bacteria from 14-d-old nodules
Bacteria from 28-d-old nodules
'Nodule bacteria' $\dagger$
'Transforming bacteria' $\dagger$
'Bacteroids' $\dagger$

RNA source

Bacteria from 14-d-old nodules

'Nodule bacteria' $\dagger$

'Bacteroids'

\begin{tabular}{|c|c|c|c|}
\hline \multicolumn{4}{|c|}{ mRNA abundance* } \\
\hline nifH & nifDK & $g \ln I I$ & $g \ln A$ \\
\hline 498 & 243 & 63 & 29 \\
\hline 636 & 205 & 66 & 15 \\
\hline 579 & 181 & 34 & 23 \\
\hline 767 & 166 & 34 & 25 \\
\hline 442 & 171 & 19 & 31 \\
\hline
\end{tabular}

* C.p.m. of hybridization probe protected from S1 nuclease digestion per $\mu$ g of input total cellular RNA. Data represent mean values determined from duplicate experiments. Variation between experiments was less than $20 \%$.

†'Developmental' cell types isolated from the total population of bacterial cells within a soybean root nodule as described in Methods.

on the change in buoyant density of bacteroids which occurs due to their accumulation of polyhydroxybutyrate (PHB) granules. The expression of certain other 'bacteroid-specific' properties (including nitrogenase enzyme activity) parallels this PHB accumulation (Ching et al., 1977). mRNA levels were analysed from the three bacterial populations distinguished by this method (see Methods). No significant differences in nifH, nifDK or $g \ln I I$ gene expression patterns were observed between the three bacterial fractions (Table 2).

\section{DISCUSSION}

Under specialized cultural conditions, several bradyrhizobial strains, including B. japonicum, are able to reduce $\mathrm{N}_{2}$ to ammonia in free-living culture (Keister, 1975; Pagan et al., 1975; Kurz \& Larue, 1975; McComb et al., 1975; Tjepkema \& Evans, 1975). Optimal conditions for asymbiotic $\mathrm{N}_{2}$ fixation include the presence of organic acids as carbon and energy source, a growth-promoting nitrogen source, and extreme microaerobiosis. Microaerobic conditions are required for $\mathrm{N}_{2}$ fixation because the nitrogenase enzyme is inactivated by intracellular $\mathrm{O}_{2}$. Some $\mathrm{O}_{2}$ is required for growth, however, as rhizobia are obligate aerobes. The highest free-living $\mathrm{N}_{2}$ fixation rates by bradyrhizobia are achieved at extremely low $\mathrm{O}_{2}$ tensions (Ludwig, 1984). We have directly studied the effect of $\mathrm{O}_{2}$ limitation of growth on transcription. The requirements for the transcriptional induction of the genes encoding the nitrogenase structural polypeptides were found to be less complex than those for achieving nitrogenase enzyme activity. High levels of several nif mRNAs were found when $\mathrm{O}_{2}$ levels were rate-limiting for growth. Extreme microaerobiosis was not required, nor were organic acids or any of the other specialized conditions previously reported (see references above) as necessary for the induction of nitrogenase activity.

In addition, we found that under these $\mathrm{O}_{2}$-limited growth conditions transcription of the $\mathrm{glnII}$ gene, encoding GSII, was induced. Neither the nif genes nor $g$ lnII were transcribed in the same medium under fully aerobic conditions: they were induced only under conditions in which growth was directly affected by availability of $\mathrm{O}_{2}$. Thus, expression of $g \ln I I$ appears to be activated coordinately with that of nif genes in response to $\mathrm{O}_{2}$ limitation. Rao et al. (1978) reported that GSII activity decreased during microaerobiosis for some bradyrhizobia. The reported inhibition of GSII activity occurred at the same $\mathrm{O}_{2}$ tension as that at which nitrogenase activity first became apparent (about $0.4 \% \mathrm{O}_{2}$ in the experiments described by Rao et al., 1978). Since no nitrogenase activity was observed in the experiments we describe, it is possible that at lower $\mathrm{O}_{2}$ concentrations glnII transcription could have been repressed. However, we observed similar levels of $g \ln I I$ transcript in total cellular RNA populations isolated from the $\mathrm{N}_{2}$-fixing bacteria in soybean root nodules and from bacteria grown in microaerobic, non- $\mathrm{N}_{2}$-fixing culture (Tables 1 and 2). If GSII is inactive in nodules and under microaerobic conditions, it is possible that expression of this enzyme is regulated by an unknown post-transcriptional mechanism. 
As shown here, the relationship between $\mathrm{O}_{2}$ and nitrogen limitation in bradyrhizobia is complex. Addition of ammonia to microaerobic cultures of $B$. japonicum in an amino-acid-based medium (YEMN) increases both growth rate and final cell density. Similar changes in growth properties can be achieved by increasing atmospheric $\mathrm{O}_{2}$ levels, indicating that the amino acids present in yeast extract do not limit aerobic growth. These data imply that growth limitation during microaerobiosis results from nitrogen limitation brought about by changes in the cells' ability to utilize amino acids as a source of nitrogen. $\mathrm{O}_{2}$ limitation has been shown to induce an ammonium export system in Bradyrhizobium sp. 32H1 (Ludwig, 1980b; Gober \& Kashkett, 1983). If such a system were induced here, nitrogen limitation could occur even if amino acids were catabolized normally, as active ammonium export would compete with its assimilation. Addition of ammonium to these cultures might then partially relieve nitrogen limitation and stimulate growth by shifting the intracellular/extracellular ammonium balance.

Of primary interest is the mechanism that controls the transcriptional induction of nif and $g \ln I I$ genes. In aerobic culture, transcription of $g \ln I I$ is mediated by an Ntr-like system (Carlson et al., 1987). When $B$. japonicum is grown aerobically under nitrogen-limiting conditions, transcription of $g \ln I I$ is induced and when nitrogen nutrition does not limit growth, $g \ln I I$ is not transcribed. Transcript levels for the nif and $g \ln I I$ genes normalized to the level of $g \ln A$ transcript are reduced by the addition of ammonium (Table 1). This result indicates that nitrogen limitation might be responsible in part for causing an Ntr-like induction of $g \ln I /$ and/or nif genes. Similar results have been observed in studies of ammonia effects on nitrogenase activity (Ludwig, 1980a, $b$; Bergerson \& Turner, 1978). Ntr-like control of nitrogenase expression has previously been described for bradyrhizobia (Ludwig, 1980a, b; Bergerson \& Turner, 1978) and rhizobia (Szeto et al., 1987). The glnII gene promoter shares sequence homology in the -10 to -25 region with $B$. japonicum nif promoters (Carlson et al., 1987) and with promoters from other bacteria that are controlled by nitrogen availability (Ntr control; Magasanik, 1982; Ausubel, 1984; Gussin et al., 1986). A gene, termed nif $A$, that is required for both microaerobic and symbiotic induction of nif and glnII gene expression in $B$. japonicum has been characterized (Fischer et al., 1986; Adams, 1986). The nif $A$ gene product acts on a DNA sequence that is found upstream of nif genes (Alvarez-Morales et al., 1986) but not upstream of the $g \ln I I$ gene (Carlson et al., 1987). Mutations in nif $A$ have no effect on the aerobic Ntr-like control of $g \ln I I$ expression (unpublished results). Taken together with the partial ammonium repression of $g \ln I I$ expression, the implication of these data is that the role of the nif $A$ product on the $\mathrm{O}_{2}$ limitation response of the $g \ln I I$ gene is indirect, possibly acting through the Ntr system. Isolation of $\mathrm{Ntr}$ mutants of $B$. japonicum defective in the aerobic Ntr-like control of $g \ln I I$ will help to clarify the microaerobic Ntr-like response described here and to define the hierarchy of nif $A$ - and Ntr-mediated control of nif gene expression in the bradyrhizobia.

We thank Mary Lou Guerinot for help in the early stages of this study. We also thank Michael Thomashow, William Timberlake and all the members of our laboratory for critical and helpful discussion. This work was supported by grant 85-CRCR-1-1739 from the US Department of Agriculture and by the US Department of Energy Division of Biological Energy Research under contract DE-AC02-76ER01-1338. This is article number 12430 from the Michigan Agricultural Experiment Station.

\section{REFERENCES}

ADAMS, T. H. (1986). Transcriptional regulation of nitrogen fixation and nitrogen assimilation genes in Bradyrhizobium japonicum. PhD thesis, Michigan State University.

Adams, T. H. \& Chelm, B. K. (1984). The nifH and nifDK promoter regions from Rhizobium japonicum share structural homologies with each other and with nitrogen-regulated promoters from other organisms. Journal of Molecular and Applied Genetics 2, 392-405.

Alvarez-Morales, A., Betancourt-Alvarez, M., KaluZA, K. \& HenNeCKE, H. (1986). Activation of the Bradyrhizobium japonicum nifH and nifDK operons is dependent on promoter-upstream DNA sequences. Nucleic Acids Research 14, 4207-4227.

AUSUBEL, F. M. (1984). Regulation of nitrogen fixation genes. Cell 37, 5-6.

Bergerson, F. J. \& TURNER, G. L. (1967). Nitrogen fixation by the bacteroid fraction of breis of soybean root nodules. Biochimica et biophysica acta 141, 507515.

Bergerson, F. J. \& TURNer, G. L. (1978). Activity of nitrogenase and glutamine synthetase in relation to availability of oxygen in continuous cultures of a strain of cowpea Rhizobium sp. supplied with excess ammonium. Biochimica et biophysica acta 538, 406416.

Bishop, P. E., Guevara, J. G., Engelke, J. A. \& Evans, H. J. (1976). On the relation between 
glutamine synthetase and nitrogenase activities in the symbiotic association between Rhizobium japonicum and Glycine max. Plant Physiology 57, 542-546.

Brown, C. M. \& DilworTh, M. J. (1975). Ammonia assimilation by Rhizobium cultures and bacteroids. Journal of General Microbiology 86, 39-48.

Carlson, T. A. \& Chelm, B. K. (1986). Apparent eucaryotic origin of glutamine synthetase II from the bacterium Bradyrhizobium japonicum. Nature, London 322, 568-570.

Carlson, T. A., Guerinot, M. L. \& Chelm, B. K. (1985). Characterization of the gene encoding glutamine synthetase I $(\mathrm{g} \ln A)$ from Bradyrhizobium japonicum. Journal of Bacteriology 162, 698-703.

CARlson, T. A., Martin, G. B. \& Chelm, B. K. (1987). Differential transcription of the two glutamine synthetase genes of Bradyrhizobium japonicum. Journal of Bacteriology (in the Press).

Ching, T. M., Hedke, S. \& Newcomb, W. (1977). Isolation of bacteria, transforming bacteria, and bacteroids from soybean nodules. Plant Physiology 60, 771-774.

Daniel, R. M., Limmer, A. W., Steele, K. W. \& SMITH, I. M. (1982). Anaerobic growth, nitrate reduction and denitrification in 46 Rhizobium strains. Journal of General Microbiology 128, 1811 1815.

DARROW, R. A. \& KNOTTS, R. R. (1977). Two forms of glutamine synthetase in free-living root-nodule bacteria. Biochemical and Biophysical Research Communications 78, 554-559.

Fischer, H.-M., Alvarez-Morales, A. \& HenNeCKe, H. (1986). The pleiotropic nature of symbiotic regulatory mutants: Bradyrhizobium japonicum nif $A$ gene is involved in control of nif gene expression and formation of determinate symbiosis. EMBO Journal 5, 1165-1173.

Gober, J. W. \& KashKetT, E. R. (1983). Methylammonium uptake by Rhizobium sp. strain $32 \mathrm{Hl}$ Journal of Bacteriology 153, 1196-1201.

Gussin, G. N., Ronson, C. W. \& Ausubel, F. M. (1986). Regulation of nitrogen fixation genes. Annual Review of Genetics 20, 567-591.

HARDY, R. W. F., HolsTEN, R. D., JACKSON, E. K. \& BURNS, R. C. (1968). The acetylene-ethylene assay for $\mathrm{N}_{2}$ fixation: laboratory and field evaluation. Plant Physiology 43, 1185-1207.

KeISTER, D. L. (1975). Acetylene reduction by pure cultures of rhizobia. Journal of Bacteriology 123, 1265-1268.

KuRz, W. G. W. \& LaRue, T. A. (1975). Nitrogenase activity in rhizobia in absence of plant host. Nature, London 256, 407-408.

KUYKendall, L. D. \& ElKan, G. H. (1976). Rhizobium japonicum derivatives differing in nitrogen fixing efficiency and carbohydrate utilization. Applied and Environmental Microbiology 32, 511-519.

LUDWIG, R. A. (1978). Control of ammonium assimilation in Rhizobium 32H1. Journal of Bacteriology 135 , 114-123.

LudwIG, R. A. (1980a). Regulation of Rhizobium nitrogen fixation by the unadenylylated glutamine synthetase I system. Proceedings of the National Academy of Sciences of the United States of America 77, 5817-5821.

LUdWIG, R. A. (1980b). Physiological roles of glutamine synthetases I and II in ammonium assimilation in Rhizobium sp. 32H1. Journal of Bacteriology 141, 1209-1216.

LUDWIG, R. A. (1984). Rhizobium free-living nitrogen fixation occurs in specialized nongrowing cells. Proceedings of the National Academy of Sciences of the United States of America 81, 1566-1569.

MAGASANIK, B. (1982). Genetic control of nitrogen assimilation in bacteria. Annual Review of Genetics 16, 135-168

Maxam, A. M. \& Gilbert, W. (1980). Sequencing end-labelled DNA with base-specific chemical cleavages. Methods in Enzymology 65, 499-580.

MсСомв, J. A., Elliot, J. \& Dilworth, M. J. (1975). Acetylene reduction by Rhizobium in pure culture. Nature, London 256, 410-412.

MeYer, M. C. \& PuePPKe, S. G. (1980). Differentiation of Rhizobium japonicum derivatives by antibiotic sensitivity patterns, lectin binding, and utilization of biochemicals. Canadian Journal of Microbiology 26, 606-612.

Miflin, B. J. \& LEA, P. J. (1976). The pathway of nitrogen assimilation in plants. Phytochemistry 15 , 873-885.

Mortenson, L. E. \& Thornley, R. N. F. (1979). Structure and function of nitrogenase. Annual Review of Biochemistry 48, 387-418.

O'GaRA, F. \& Shanmugan, K. T. (1976). Regulation of nitrogen fixation by Rhizobia export of fixed $\mathrm{N}_{2}$ as $\mathrm{NH}_{4}$. Biochimica et biophysica acta 437, 313-321.

Pagan, J. D., Child, J. J., Scowcroft, W. R. \& GIBSON, A. H. (1975). Nitrogen fixation by Rhizobium cultured on a defined medium. Nature, London 256, 406-407.

Rao, V. R., Darrow, R. A. \& KeISTeR, D. L. (1978). Effect of oxygen tension on nitrogenase and on glutamine synthetases I and II in Rhizobium japonicum 61A76. Biochemical and Biophysical Research Communications 81, 224-231.

ScotT, D. B., Hennecke, H. \& Lim, S. T. (1979). The biosynthesis of nitrogenase MoFe protein polypeptides in free-living cultures of Rhizobium japonicum. Biochimica et biophysica acta 565, 365-378.

SOMER Ville, J. E. \& KAHN, M. L. (1983). Cloning of the glutamine synthetase I gene from Rhizobium meliloti. Journal of Bacteriology 156, 168-176.

STRIPF, R. \& WERNER, D. (1978). Differentiation of Rhizobium japonicum. II. Enzymatic activities in bacteroids and plant cytoplasm during the development of nodules of Glycine max. Zeitschrift für Naturforschung 33c, 373-381.

Szeto, W. W., Nixon, B. T., Ronson, C. W. \& AUSUBEL, F. M. (1987). Identification and characterization of the Rhizobium meliloti ntrC gene: $R$. melilot $i$ has separate regulatory pathways for activation of nitrogen fixation genes in free-living and symbiotic cells. Journal of Bacteriology 169, 1423 1432.

TJEPKEMA, J. \& Evans, H. J. (1975). Nitrogen fixation by free-living Rhizobium in a defined liquid medium. Biochemical and Biophysical Research Communications 65, 625-628.

Werner, D., Morschel, E., Stripf, R. \& WinchenBACH, B. (1980). Development of nodules of Glycine max infected with an ineffective strain of Rhizobium japonicum. Planta 147, 320-329. 